\title{
Sameness-difference matching from sample by chimpanzees
}

\author{
HARRIET J. SMITH, JAMES E. KING, EDWIN D. WITT, and JOHN E. RICKEL \\ University of Arizona, Tucson, Arizona 85721
}

\begin{abstract}
Two adult chimpanzees were trained on a sameness-difference matching from sample task with five levels of difficulty, ranging from a simple form of matching from sample in Phase 1 , to a fully generalized form of matching from sample in Phase 5. The development of hypotheses by both subjects during each phase was analyzed. In Phase 1 , both animals initially showed considerable position and random responding, both of which decreased as correct and 2/3-correct responding increased. In all later phases, however, position responding was minimal, random responding characterized the beginning of each phase, and correct responding characterized the end of each phase.
\end{abstract}

Recent evidence has clearly demonstrated that chimpanzees are highly adept at learning concepts which depend upon differential responding to homogeneous and heterogeneous classes of stimuli. For example, Premack (1971) was able to train a chimpanzee to respond appropriately to various types of interrogative sentences based upon whether two presented stimuli were identical or different. King (1973), with a more conventional testing procedure, showed that chimpanzees and orangutans could learn one sameness-difference learning set based on color cues while simultaneously learning another sameness-difference learning set based on shape cues when one of the learning sets required the subject to choose homogeneous stimuli, and the other required the subject to choose heterogeneous stimuli. The chimpanzees' flexibility in making samenessdifference discriminations strongly suggests that this species should readily be able to learn a samenessdifference discrimination based upon a matching from sample principle.

The experiment described here was designed to provide a detailed quantitative description of the learning of a sameness-difference matching from sample task by chimpanzees. We were specifically interested in tracing the development of the subjects' hypotheses (King \& Fobes, 1975; Levine, 1965) manifested during the course of learning. The experiment consisted of five phases of increasing difficulty which ranged from a relatively simple matching from sample task in Phase 1 to a generalized form of sameness-difference matching from sample in Phases 5 and 6.

\section{METHOD}

\section{Subjects}

The subjects in this study were two adult chimpanzees

This study was partially supported by Public Health Service grant MH-11286. The authors would lik. to express their appreciation to Dr. Howard H. Purcell, Jr., owner of Genus Pan Research Station, for his generous help in the completion of this study. We also wish to acknowledge the capable assistance of Marilyn Meyer and Richard McLeod.
(Pan troglodytes), one male (Casey) and one female (Lola). Neither animal had been previously tested on any type of learning task. The subjects were housed at the Genus Pan research station near Laveen, Arizona.

\section{Apparatus}

A modified version of the manually operated Wisconsin General Test Apparatus (WGTA) was used. The stimulus presentation tray measured $28 \times 41 \mathrm{~cm}$ and contained two foodwells, $21 \mathrm{~cm}$ apart. The apparatus was constructed so that it could be rolled to the front of the subjects' home cages for testing.

The stimulus objects used in all phases except Phase 6 were plywood squares, triangles and Block C forms, $3.5 \times 3.5 \times$ $1.27 \mathrm{~cm}$, and painted red, green, or white. In Phases 1-5, a total of nine unique stimulus objects defined by all possible combinations of these three forms and three colors were used. In Phase 6, nine unique stimuli also measuring $3.5 \times 3.5 \times$ $1.27 \mathrm{~cm}$ were used, but the forms (Block Ms, Zs, and hexagons) and the colors (blue, yellow, and black) used were different than those used in Phases 1-5 (see Figure 1).

Three Plexiglas bins were used to enclose the arrays of stimuli on each trial. The center bin was immovable and always contained the sample stimuli. Bins on either side of the stationary bin could be displaced by the subject to reveal a foodwell, and M\&M candy reinforcers were placed in the positive foodwell. The movable side bins contained the discriminative stimuli.

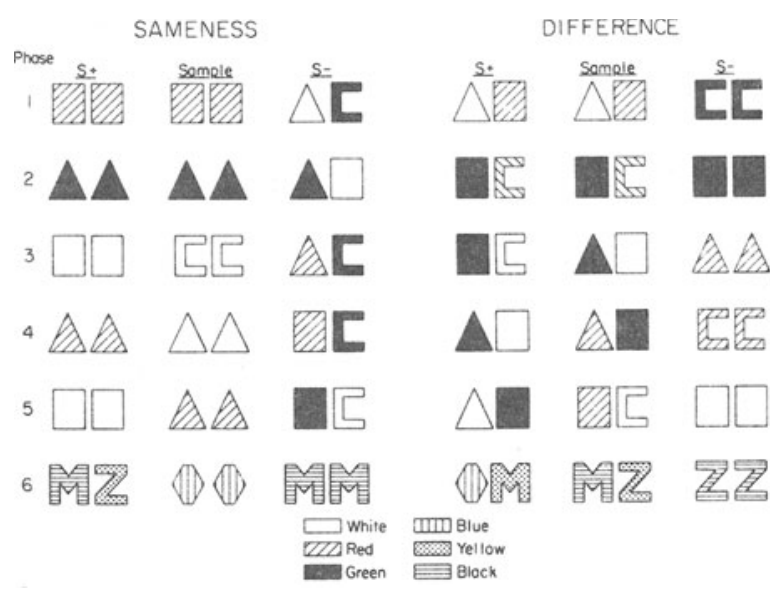

Figure 1. Examples of stimulus arrays presented in Phases 1-6. 


\section{Test Procedure}

At the start of each trial, the experimenter opened the sliding opaque panel of the WGTA and pushed the stimulus tray forward to within reach of the subject. The subject then made a choice by displacing one of the side bins. If the choice was correct, the subject removed the candy from the foodwell beneath the bin, and the experimenter then removed the tray. If the choice was incorrect, the tray was removed immediately. A noncorrection procedure was used throughout.

Each subject received 48 training trials daily, consisting of 16 three-trial blocks. If the criterion of 19 out of 20 correct responses was reached before 48 trials were completed, testing was terminated, and work on the next phase was begun the following test day. The correct position of the stimulus objects varied randomly with the restriction that all possible three-trial left-right sequences occurred equally often.

\section{Experimental Design}

A sameness-difference matching from sample task was used in all phases. The correct rule in all phases was that the pair of stimuli most closely matching the sample stimuli with respect to homogeneity/heterogeneity was the positive stimulus pair (S+). On all test days, homogeneous and heterogeneous sample configurations each appeared in eight three-trial blocks.

Figure 1 shows examples of stimulus arrays for trials in each phase.

Phase 1. The S+ matched the sample stimuli with respect to both color and form, while the $S$ - did not match the sample with respect to either color or form.

Phase 2. The S+ matched the sample with respect to color and form, and one of the objects in the S-matched the sample with respect to color and form.

Phase 3. The S+ matched the sample with respect to color but not form.

Phase 4. The S+ matched the sample with respect to form but not color.

Phase 5. In this phase, the S+ did not match the sample exactly with respect to form or color. The $S+$ and the sample matched only with respect to homogeneity/heterogeneity.

Phase 6. Phase 6 was identical to Phase 5 except that the new set of nine stimulus objects previously described was used.

\section{RESULTS}

Casey reached the criterion of 19 out of 20 correct responses on each of Phases 1 through 5 and then achieved 130 correct responses on the 192 trials presented in Phase 6. His above chance performance during Phase $6(\mathrm{z}=4.91, \mathrm{p}<.00001)$ clearly demonstrated that he had learned a generalized concept of samenessdifference matching from sample. Lola achieved criterion performance on Phases 1 through 4, after which testing was discontinued for reasons not related to her performance.

A modified version of Levine's (1965) hypothesis analysis technique similar to that used by King and Fobes (1975) was used to measure the strengths of hypotheses manifested by each subject during each phase. Three-trial response sequences were partitioned into cells of a 64-cell matrix in which 32 cells applied to problems with a homogeneous sample, and the remaining 32 cells applied to problems with a heterogeneous sample. The 11 measured hypotheses and their possible manifestations are shown in Table 1.

Figure 2 shows the proportional strengths of all hy-
Table 1

Measured Hypotheses and Their Possible Manifestations

\begin{tabular}{|c|c|c|}
\hline Hypotheses & Definitions & Manifestations \\
\hline All correct & $\begin{array}{l}\text { Response to the } \\
\text { rewarded stimu- } \\
\text { lus pair }\end{array}$ & +++ \\
\hline $2 / 3$ correct & $\begin{array}{l}\text { Response to the } \\
\text { rewarded stimu- } \\
\text { lus pair } 2 \text { trials } \\
\text { out of } 3\end{array}$ &,,++-+-+-++ \\
\hline Sameness & $\begin{array}{l}\text { Response to the } \\
\text { homogeneous } \\
\text { pair }\end{array}$ & $\begin{array}{l}+++ \text { when sample contains } \\
\text { homogeneous pair; }--- \\
\text { when sample contains hete- } \\
\text { rogeneous pair }\end{array}$ \\
\hline Difference & $\begin{array}{l}\text { Response to the } \\
\text { heterogeneous } \\
\text { pair }\end{array}$ & $\begin{array}{l}++ \text { when sample contains } \\
\text { heterogeneous pair; --- } \\
\text { when sample contains } \\
\text { homogeneous pair }\end{array}$ \\
\hline $\begin{array}{l}\text { Stimulus pre- } \\
\text { ference* }\end{array}$ & $\begin{array}{l}\text { Sequence of re- } \\
\text { sponses to a par- } \\
\text { ticular object }\end{array}$ & $\begin{array}{l}-+,-+-,+-- \text { when } \\
\text { sample contains homogen- } \\
\text { eous pair; }++-,+-+,-++ \\
\text { when sample contains hete- } \\
\text { rogeneous pair }\end{array}$ \\
\hline $\begin{array}{l}\text { Stimulus } \\
\text { aversion* }\end{array}$ & $\begin{array}{l}\text { Sequence of re- } \\
\text { sponses that } \\
\text { avoid a particu- } \\
\text { lar object }\end{array}$ & $\begin{array}{l}++,+-+,-+ \text { when } \\
\text { sample contains homogen- } \\
\text { eous pair; }--+,-+-,+-- \\
\text { when sample contains hete- } \\
\text { rogeneous pair }\end{array}$ \\
\hline $\begin{array}{l}\text { Position pre- } \\
\text { ference }\end{array}$ & $\begin{array}{l}\text { Sequence of re- } \\
\text { sponses to one } \\
\text { side }\end{array}$ & III \\
\hline $\begin{array}{l}\text { Position } \\
\text { alternation }\end{array}$ & $\begin{array}{l}\text { Alternating be- } \\
\text { tween positions } \\
\text { on consecutive } \\
\text { trials }\end{array}$ & IOI \\
\hline $\begin{array}{l}\text { Win-stay; } \\
\text { lose-shift, } \\
\text { position }\end{array}$ & $\begin{array}{l}\text { Response to po- } \\
\text { sition rewarded } \\
\text { on } \\
\text { trial }\end{array}$ & $\begin{array}{l}\mathrm{I}+\mathrm{I}+\mathrm{I}, \mathrm{I}+\mathrm{I}-\mathrm{O}, \mathrm{I}-\mathrm{O}+\mathrm{O}, \mathrm{I}- \\
\mathrm{O}-\mathrm{I}\end{array}$ \\
\hline $\begin{array}{l}\text { Win-shift; } \\
\text { lose-stay, } \\
\text { position }\end{array}$ & $\begin{array}{l}\text { Response to po- } \\
\text { sition not rewar- } \\
\text { ded on preced- } \\
\text { ing trial }\end{array}$ & $\begin{array}{l}\mathrm{I}-\mathrm{I}-\mathrm{I}, \\
\mathrm{I}+\mathrm{O}+\mathrm{I}\end{array}$ \\
\hline Random & $\begin{array}{l}\text { Response not } \\
\text { correlated with } \\
\text { stimulus change } \\
\text { or position }\end{array}$ & All sequences \\
\hline
\end{tabular}

Note-+ indicates a correct response, - indicates an incorrect response. I indicates the position selected on the first trial of a three-trial sequence. $O$ indicates the other position.

*Measured in Phase 1 only.

potheses exhibited by both chimpanzees in Phases 1 through 4 and by Casey in Phases 5 and 6. At the start of Phase 1, both subjects showed substantial amounts of random responding and position preference while all other hypotheses had negligible strengths. As learning proceeded in Phase 1 , random and position responding decreased sharply as correct and $2 / 3$ correct responding increased. With the introduction of succeeding phases, changes in hypotheses strengths for both subjects followed a strikingly simple pattern. The changes in stimulus presentation rules from phase to phase typically resulted in a reduction of correct and $2 / 3$ correct responding and a concomitant increase 


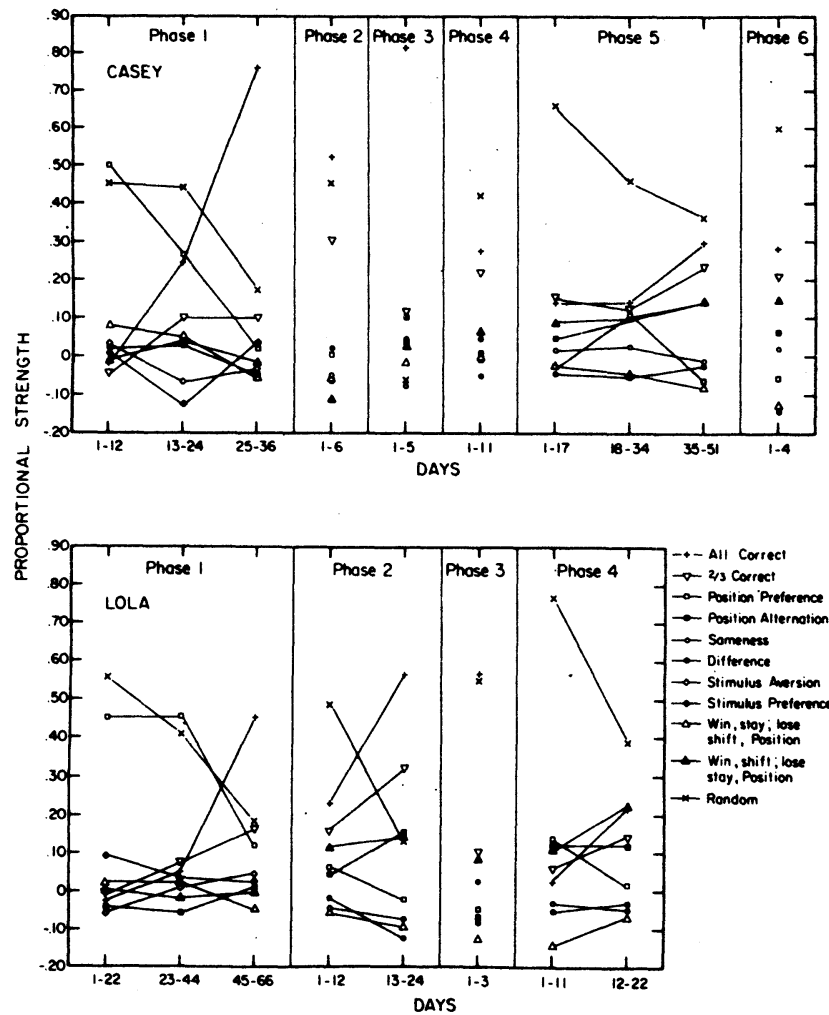

Figure 2. Proportional strengths of hypotheses manifested by Casey in Phases 1-6 and by Lola in Phases 1-4.

in random responding, while all other hypotheses including position responding remained at close to zero strength.

\section{DISCUSSION}

The results of this experiment demonstrated that chimpanzees can learn a generalized form of the sameness-difference matching from sample concept. In particular, the learning in Phase 5 showed that the concept can be mastered when the sample configuration contains stimulus objects different from those in the S+ configuration and therefore shares only the property of homogeneity or heterogeneity with the S+. The above chance performance in Phase 6 showed that a sameness- difference matching from sample learned with one set of stimulus objects is readily generalized to testing with an unfamiliar set of stimulus objects.

The hypothesis analysis revealed that after an initial abundance of position responding, both chimpanzees abandoned this hypothesis and error increases at the start of subsequent phases were almost entirely associated with increases in random responding. This pattern of hypothesis manifestation by chimpanzees is remarkably similar to the pattern shown by fastlearning monkeys during acquisition of complex samenessdifference concepts. For example, King and Fobes (1975) showed that capuchin monkeys who rapidly learned a samenessdifference learning set evidenced more pronounced and persistent random responding than did capuchin monkeys who were slow learners. In contrast, the slow-learning monkeys were markedly, more susceptible to position responding. Scanlon and King (Note 1) observed a similar difference between slowand fast-learning capuchin monkeys during acquisition of a discrimination between ABA and BBA configurations.

The above results suggest that successful solution of complex concepts by primates is associated with: (1) rapid and permanent elimination of position responding during the initial stages of learning, and (2) errors in the later stages of learning being mainly attributable to random responding rather than to any systematic error producing strategy.

\section{REFERENCE NOTE}

1. Scanlon, J., \& King, J. E. Transposition along a homogeneity/heterogeneity dimension by capuchin monkeys. Unpublished manuscript, 1975. (Available from author's address.)

\section{REFERENCES}

KING, J. E. Learning and generalization of a two-dimensional sameness difference concept by chimpanzees and orangutans. Journal of Comparative and Physiological Psychology, 1973. 84, 140-148.

KING, J. E., \& Fobes, J. L. Hypothesis analysis of samenessdifference learning-set by capuchin monkeys. Learning and Motivation, 1975, 6, 101-113.

Levine, M. Hypothesis behavior. In: A. M. Schrier \& F. Stollnitz (Eds.), Behavior of nonhuman primates (Vol. 1). New York: Academic Press, 1965.

Premack, D. On the assessment of language competence in the chimpanzee. In: A. M. Schrier \& F. Stollnitz (Eds.), Behavior of nonhuman primates (Vol. 4). New York: Academic Press, 1971

(Received for publication July 7, 1975.) 